\title{
SHIFTING GROUND, SOLID FOUNDATIONS: IMAGINING A NEW PARADIGM FOR CANADIAN CIVIL SOCIETY ENGAGEMENT
}

\section{Nandini Ramanujam \\ Miatta Gorvie*}

Members of civil society are increasingly decrying what they identify as an insidious trend whereby the government is targeting organizations whose mandates run contrary to the federal government's political and economic agendas and creating a chill around public policy and advocacy work. The media as well as civil society organizations [CSOs] themselves have documented government attempts to undermine and stifle the voices of dissenting organizations, ranging from rhetorical attacks to the withdrawal of funding for ambiguous reasons. The climate of resentment and suspicion between civil society actors and the government is detrimental for safeguarding the tradition of accountability and transparency in Canada's democratic institutions. Amidst this turbulent environment, this paper examines the often-made claim by CSO leaders in Canada that public funding is a necessary requirement for a strong civil society, with the aim of challenging and mobilizing the civil society community to not only survive but to reinvigorate its engagement to further social justice in this changing social and economic landscape. We argue that discussions of the state of civil society in Canada focus disproportionately on the question of funding and relationship-building with the government and expose the unforeseen consequences of this trade-off for CSOs, their members, and constituent communities. We close by introducing the potential of a new paradigm of "principled engagement" that would allow Canadian CSOs to thrive as sustainable, adaptable social justice advocates in coming years.

Les membres de la société civile décrient de plus en plus ce qu'ils appellent la tendance insidieuse du gouvernement à cibler les organisations dont les mandats vont à l'encontre de ses programmes politiques et économiques et à freiner le travail de représentation et de plaidoyer lié aux politiques publiques. Tant les médias que les organisations de la société civile [OSC] ont déploré les tentatives du gouvernement de faire taire les voix d'organisations dissidentes, que ce soit par des attaques rhétoriques ou par le retrait du financement pour des raisons ambiguës. Le climat de ressentiment et de doute qui règne entre les intervenants de la société civile et le gouvernement nuit au maintien de l'imputabilité et de la transparence qui caractérisent depuis longtemps les institutions démocratiques canadiennes. Dans ce contexte de turbulence, les auteurs de ce texte répondent aux dirigeants des OSC du Canada qui ne cessent de répéter qu'une société

Nandini Ramanujam, Associate Professor (Professional), Faculty of Law, McGill University; Executive Director and Director of Program of the McGill Centre for Human Rights and Legal Pluralism.

Miatta Gorvie is a graduate of the B.C.L./LL.B. program of McGill University and a former Aisenstadt Student Research Fellow of the McGill Centre for Human Rights and Legal Pluralism. 
civile forte a besoin à tout prix de fonds publics afin de mobiliser ses intervenants et de les encourager non seulement à survivre, mais également à réitérer leur engagement à promouvoir la justice sociale dans ce climat socio-économique changeant. Nous affirmons quant à nous que la société civile du Canada accorde trop d'importance à la question du financement et de l'établissement de relations avec le gouvernement et nous évoquons l'émergence possible d'un nouveau paradigme selon lequel les OSC canadiennes pourraient s'imposer comme des représentants de la justice sociale solides et capables de s'adapter aux changements au cours des années à venir.

\section{INTRODUCTION}

Canadian civil society has exhibited signs of deep distress in recent years. Members of civil society and commentators are increasingly decrying what they identify as an insidious trend where civil society organizations [CSOs] are being "aggressively targeted" by a "government that seems hostile to their concerns." "This targeting is said to have led to a "chill around public policy and advocacy work." 3 The CSOs (also known as non-governmental or non-profit organizations) that have come under government scrutiny are typically those tackling the structural issues underlying poverty, access to justice, labour rights, alternative approaches to criminal law, women's health and family planning, and environmental sustainability. ${ }^{4}$ CSOs and the media have documented an array of government attempts to undermine and stifle the voices of dissenting organizations, ranging from rhetorical attacks ${ }^{5}$ to the withdrawal of federal government funding for ambiguous reasons. ${ }^{6}$ The deteriorating climate of resentment and suspicion between civil society actors and the government is detrimental for safeguarding the tradition of accountability and transparency in Canada's democratic institutions.

Reports documenting the systematic erosion of a once-conducive environment for CSOs usually identify the Stephen Harper-led Conservative government for the current state of affairs. While growing evidence of administrative unfairness suggests that the government is deploying a range of restrictive measures to create a harsh and punitive environment for dissenters, the dramatic cuts in federal funding to the CSO sector is the often-cited yardstick used to highlight its hostile attitude. ${ }^{7}$ The focus on funding

1 Hélène Laverdière, “The Conservatives need to stop attacking Canada’s NGOs,” The Huffington Post (5 May 2013) online: <http://www.huffingtonpost.ca>.

2 John W Foster, "Obama, Canada, and civil society", Canada Watch (Fall 2010) at 6, online: Robarts Centre for Canadian Studies $<$ http://robarts.info.yorku.ca $>$.

3 Jennifer Ditchburn, "Wealthy foundations way of Harper's crackdown on charities", The Globe and Mail (9 May 2012) online: < http://www.theglobeandmail.com>.

4 Voices-Voix Coalition, Documenting the silencing of Canadian voices, online: Voices-Voix Coalition $<\mathrm{http}: / /$ voicesvoix.ca/> [Voices Documentation Project].

5 Robert W Peterson, "Senator to Harper Government: stop 'slandering' charities", The Tyee (7 June 2012) Editorial, online: <http://thetyee.ca $>$.

6 Kim Mackrael, “Ottawa ignored CIDA green light when it halted aid group's funding”, The Globe and Mail (27 October 2010) online: The Globe and Mail < http://www.theglobeandmail.com>.

7 See for e.g. Dave Coles, "Bill C-377: What you need to know about the latest Conservative attack on civil society", Rabble.ca (2 October 2012) online: Rabble <http://rabble.ca>; John W Foster, supra note 2; Lawyers Rights Watch, "The Shrinking Space for Dissent in Canada: Written Statement to the 26th Session of the UN Human Rights Council" (May 2014) Voices-Voix Documentation Project, online: Voices-Voix < http:/voices-voix.ca/>; Pearl Eliadis, Nikki 
is understandable as most Canadian non-profits have traditionally relied on generous grants and contracts from the government to sustain their operations. ${ }^{8}$ Organizations that pursue program and policy agendas in perceived conflict with those of the government - many of which have received sustained public funding for decades - have been newly scrutinized. Selective program audits, revocation of charitable status or the threat thereof, and the refusal to renew funding have been some of the tactics used by the government to undermine or shut down the operation of many non-profit organizations. ${ }^{9}$ In a liberal democratic context such as Canada's, the growing influence of a more reactionary political ideology in the allocation of public funding for social justice and human rights organizations is a serious cause for concern. The often-made claim by CSO leaders in Canada that public funding is a necessary requirement for a strong civil society, ${ }^{10}$ however, calls for a thorough examination.

Amidst this turbulent environment, this paper seeks to challenge and encourage the civil society community to not only endure but to reinvigorate its engagement to further social justice in today's changing social and economic landscape. The exit of Stephen Harper's Conservative government in the October 2015 election may ease the pressure on the CSO sector in the short-term, however, the structural issues raised in this article remain pertinent to the effectiveness and vibrancy of the CSO sector in Canada. We argue that discussions of the state of affairs of civil society in Canada focus disproportionately on the question of funding and relationship-building with the government. This focus is unhelpful at best, and at worst, may serve to exacerbate the type of structural imbalances that social justice CSOs seek to fight against. Those working in the public interest should resist the seductive narrative that the election of Justin Trudeau's Liberal majority has signalled a return to an idealized, historical Canada and new happy days for civil society organizations, as we will demonstrate that some of the largest cuts to public funding for civil society in the modern era were undertaken by the Liberal government in the early 1990s.

First, we address a tendency in popular discussions of civil society in Canada, in which the concept of civil society is often conflated with what is more accurately described as the "civil society sector." Numerous conceptions of civil society exist and in combining them, we can better understand the challenges, and formulate courses of action in response. There is also a divergence in approaches to civil society action in Canada, even though a consensual approach is often assumed in discussions of civil society policy. Part II situates this issue in the context of these ongoing debates and provides an overview of the regulatory framework governing charitable organizations. Second, we attempt to demonstrate that the level of government funding for CSOs is but one part of the analysis of civil society, albeit one that has become imperative for the survival of many organizations. In order to gain better insights into the current situation, it is important to go beyond the discussion on recent funding cuts and trace back the recent history of the changing relationship between the CSO sector and the

Skuce \& Fraser Reilly-King, "Silencing voices and dissent in Canada" State of Civil Society 2013: Creating an enabling environment (Johannesburg: World Alliance for Citizen Participation, CIVICUS, 2013), online: CIVICUS

$<$ http://socs.civicus.org/wp-content/uploads/2013/04/2013StateofCivilSocietyReport_full.pdf>. Michael Hall et al, "The Canadian nonprofit and voluntary sector in comparative perspective" (2005), online: Imagine Canada < http://sectorsource.ca/sites/default/files/resources/files/jhu_report_en.pdf>.

9 Voices Documentation Project, supra note 4.

10 Gerald Caplan, "Stephen Harper and the tyranny of a majority government", The Globe and Mail (15 June 2012), online: The Globe and Mail < http://www.theglobeandmail.com>. 
government. We consider these issues in Part III, as we sketch the development of the CSO sector in the context of the development of Canadian governance.

Third, even though the existing governance structure places constraints on organizations, CSOs still make calculated bargains and trade-offs in their attempts to secure greater access to the sphere of governance. These choices implicate issues of representation, identity, and values, both across civil society organizations and within them. In Part IV, we discuss the consequences of the trade-offs that leading CSOs have made in their attempts to institutionalize their place in governance spheres and secure federal government funds, only to discover that these attempts may undermine social justice projects in the long run. Fourth, the question of CSO funding is intimately linked to the character of the relationship of civil society to the state. Some governments will warmly welcome CSOs to decisionmaking platforms, while others will resist and attempt to delegitimize collective social involvement in governance, as the recent leadership has done. Regardless of a particular government's stance toward civil society, the nature of this relationship is already conditioned by the particular institutional shape of Canadian governance, therefore this collaboration is likely to produce predictable, unsatisfying outcomes for CSOs. Part IV assesses the costs of seeking a consensus-based relationship with the state, and makes a case for a new paradigm of CSO engagement.

Lastly, we illustrate how CSOs can attempt to chart a path between consensus and conflict in their engagement with the state. Resisting the full domestication of civil society by the state but also acknowledging the need for some organizations to continue to work as partners or within state structures, we suggest that CSOs that need to continue to engage with the government adopt an approach of principled engagement. By way of conclusion in Part $\mathrm{V}$, we elaborate the spirit of principled engagement and attempt to demonstrate how this idea can be operationalized by organizations so that they can continue to work as sustainable, adaptable social justice advocates in the coming years.

Far from taking a position against government funding of CSOs, we suggest that the discourse on the strength of Canadian civil society is disproportionately focused on funding and the policy and regulatory processes that govern voluntary organizations' relationship with government. This focus distracts from a meaningful discussion of the substantive principles that should underlie this relationship to the state and also sidelines organizations' interrogation of the ways in which this relationship affects their internal structures and political legitimacy. It goes without saying that funding is a crucial part of organizations' ability to carry out their mandates effectively and sustainably, but the idea that the more resources the state dedicates to civil society groups, the more good or just the state becomes, is perhaps misguided. In the search for greater access and support from the government, leading organizations and individuals in the Canadian civil society sector appear to have made a poor trade-off. It may be the case that the greater availability of government funding places organizations in a state of dependency that can distort the achievement of their social justice goals.

Civil society action informed by a spirit of principled engagement means that instead of pursuing an agenda based on an idealized understanding of Canada, CSOs and their leaders should pursue agendas based on the realities of Canadian governance and society, while being mindful of their own power as political actors and the implications of their choices. The idea of principled engagement as the guiding spirit of the Canadian civil society sector is not only a prescriptive framework but is also a descriptive one: looking to the history of the sector on the national stage, the sum of the policy discourse and actions of CSOs suggests an attempt to pursue a strategy of principled engagement at various points, to varying 
degrees of success. The question of state funding and support remains an important point to settle, but it must be preceded by introspection on the part of individual organizations and serious consideration by coalitions of organizations to establish the normative foundation of future relations with the government.

\section{CIVIL SOCIETY ORGANIZATIONS AS SOCIAL JUSTICE ADVOCATES}

The purpose of this section is to contextualize our discussion of the Canadian civil society sector and the organizations within it. We use an interdisciplinary lens to analyze the development of Canadian CSOs. This paper is informed by the body of literature on government policy on CSOs and non-profits in Canada, historical analyses of modern Canadian governance, and insights from political theorists on civil society. Of several possibilities, we have chosen to employ the terms "civil society sector" and "civil society organization" [CSO] or "non-profit organization." 11 Together, these terms allow us to consider the organizational dynamics of CSOs or non-profits as individual entities, the sphere of such organizations as a sector in Canadian governance networks, as well as the relevance of civil society as a concept in political thought. We will first elaborate on what is meant by the term "civil society", as there are multiple and overlapping definitions at use in the literature. Next, we will introduce competing visions of the function of civil society and the principles that should underlie its relations to the state. Lastly, we provide an overview of the regulatory framework governing CSO action.

\section{A. Conceptual Clarity}

In popular dialogues on civil society, there is a tendency to conflate the idea of civil society and what might be better understood as the civil society sector. This reflects the predominance of the view of civil society as strictly associational, in which civil society is a structure beyond the state, market, and family, made up of "formally registered NGOs of many different kinds, labour unions, political parties, churches and other religious groups, professional and business associations, community and self-help groups, social movements and the independent media." ${ }^{, 12}$ As a consequence of the predominance of this view of civil society in government and non-profit circles, discussions about threats to the civil society sector in Canada are usually more about the state of civil society organizations.

Our discussion focuses on CSOs with mandates related to distributive or social justice, defined broadly as seeking to prevent or alleviate the effects of social, political, and economic inequities. These organizations may have tangible or aspirational goals; they may engage in service provision, representational or interest-based politics (advocacy), research, developing alternative social policies, or some combination thereof. ${ }^{13}$ According to the most recent Statistics Canada estimates, this type of

11 The civil society sector is also referred to as the voluntary sector or the third sector. Other terms for civil society organizations include non-governmental organizations (NGOs), non-profit organizations or non-profits, and voluntary organizations.

12 Michael Edwards, Civil Society, 2d ed (Cambridge: Polity Press, 2009) at 20.

13 Such organizations, with primary goals to "serve others, to provide goods and services (including information and advocacy) to those in need or otherwise to contribute to the general welfare" have been dubbed "public benefit organizations" by Lester Salamon, Partners in Public Service: Government-nonprofit Relations in the Modern Welfare State (Baltimore: Johns Hopkins University Press, 1995) at 54. 
organization accounts for $35 \%$ of the non-profit and voluntary sector organizations in Canada. ${ }^{14}$ These organizations work in service provision; grant-making, fundraising, and voluntarism promotion; community development and housing; environmental issues; law, advocacy, and politics; and international issues. ${ }^{15}$ The vast majority of Canadian civil society employees and volunteers are engaged in service provision, as opposed to "expressive functions," which includes advocacy, community organizations, human rights groups, and environmental groups. ${ }^{16}$ By some measures, Canada has the largest non-profit sector in terms of paid employees (per capita) in the world, ${ }^{17}$ a statistic that is touted as a point of pride by members of the civil society sector and government alike.

A strictly associational understanding of civil society, however, is not the most productive approach for groups interested in social justice causes. Firstly, the number of civil society organizations in a given state does not necessarily correlate to a greater prevalence of emancipatory social values or politics. The category encompasses such a wide range of groups that it tells us little about the character of participatory politics in a country; a hockey club, a radical eco-justice movement, and a professional association are all civil society organizations. When understood as a mere assemblage of non-state, nonmarket voluntary associations, the concept can be mobilized from a range of political, economic, and social perspectives with divergent visions of justice. Taking for example the lobbying in the lead-up to Canada's legalization of same-sex marriage in 2005: the religious organizations opposed to the legislation were as much a part of civil society as the queer and human rights NGOs supporting it. At worst, the category of civil society can encompass groups that actively promote hate and bigotry, which have been referred to as "uncivil society." 18 Therefore, we see that the equation of a large civil society sector with a sphere of social actors that is democratic or transformative may be misguided.

Deepening our understanding of civil society will allow us to engage with the problems facing Canadian CSOs in a more robust way. CSOs are of course an integral part of civil society, but examining associations in isolation gives us an incomplete portrait of the problems facing them. Civil society can be understood quite simply as public space or the arena of social action. ${ }^{19}$ Rather than focusing simply on the number and relative position of CSOs in relation to the state, this view considers the civil society as a space that provides constraints and opportunities for action. Civil society as public space is a call for truly participatory politics, in which citizens actively take part in the shaping of societal goals, often through associations but not necessarily.

A broader approach to civil society allows us to gain better insights into the challenges facing CSOs and the varied and dynamic ways that power is exercised in governance. The associational view shows us the ways that government decisions either help or hinder CSOs, and in turn, the ways that civil

14 Statistics Canada, Cornerstones of Community: Highlights of the National Survey of Nonprofit and Voluntary Organizations (Ottawa: Statistics Canada, 2003) at 14 [NSNVO Report]. This total is the sum of the organizations involved in social services, environment, community development and housing, law, advocacy and politics, grantmaking, fundraising and voluntarism promotion, and international.

15 Ibid at 14. The other categories of non-profit and voluntary organizations surveyed by the NSNVO, from most to least prominent, are sports and recreation; religion; arts and culture; business, professional associations and unions; education and research; health; hospitals; universities and colleges, and unclassified organizations.

16 Ibid at 12-13.

17 Hall et al, supra note 8 at 9.

18 Simone Chambers \& Jeffrey Kopstein, "Bad Civil Society” (2001) 29:6 Political Theory 837.

19 Edwards, supra note 12 at 68. 
society actors can successfully lobby the state in return. However, organizations do not only experience power as pressure from the state, and the public space approach to civil society can show us how CSOs also make decisions that condition the contours of their space for participation in governance, as we discuss in Part III. The public space argument illuminates the realities of power "between and across civil society organizations" as well. ${ }^{20}$ Part IV of this paper provides examples of how the CSO sector in the media and in policy forums often obscures the structural imbalances within the sector itself, which allows these problems to become entrenched. Lastly, by adding the consideration of civil society as values to our critique, we can evaluate the discursive implications of the political decisions made by CSOs as they carved a space in Canadian governance and the extent to which they help or hinder the promotion of social justice aims.

\section{B. Regulatory Context}

Over half of Canada's CSOs are registered as charities with the federal government. ${ }^{21}$ Due to the origins of the Canadian voluntary sector as Victorian-era charities that focused on caring for the poor and sick and providing education and religious instruction, ${ }^{22}$ the expectation of non-profits to primarily provide charitable services endures in the current law and regulations. The charity regime is established by the Income Tax Act and governed by the Canada Revenue Agency [CRA], which has the power to grant or deny status and audit organizations for breach of the Act. For CSOs that desire it, charitable status is incredibly important as it makes them eligible for certain sources of funding, confers tax exemptions on the organization, and gives the organization the right to issue tax receipts to qualified donors. Of course, the granting of this special status comes with corresponding limitations. To benefit from charity status, the organization must have a charitable purpose, as opposed to a political purpose. ${ }^{23}$ As the Act does not define what is "charitable," the government derives its definition from the common law, which relies on the interpretation of an 1891 decision from the United Kingdom's House of Lords, which relied on the definition of a $17^{\text {th }}$ century statute governing charities. ${ }^{24}$ Therefore, a "charitable purpose" is defined as one intended to relieve poverty, advance religion, advance education. ${ }^{25}$ Failing one of these categories, a charitable purpose can be some other "public benefit," which must help an identifiable group but must be "reasonably recognized and realistically to be provided, as opposed to merely speculative, putative, or hoped-for." ${ }^{26}$ We see how this presents a barrier for organizations interested in working towards aspirational social justice aims.

20 John Gaventa, "Civil, Society and Power" in Michael Edwards, ed, The Oxford Handbook of Civil Society (Oxford: Oxford University Press, 2011) at 2.

21 In 2003, Statistics Canada estimated that 56\% of all nonprofits were registered charities. NSNVO Survey, supra note 14 at 20 .

22 Mariana Valverde, “The Mixed Social Economy as Canadian Tradition”, (1995) 47 Studies in Political Economy 33.

23 Canada Revenue Agency, Policy Statement CPS-022, Political Activities (2003), online: Canada Revenue Agency $<$ http://www.cra-arc.gc.ca $>$ at 4 [Political Activities Policy].

24 The Commissioners for the Special Purposes of Income Tax v Pemsel [1891] UKHL 1[1891]; Charitable Uses Act, 1601 (Eng.), 43 Eliz. 1, c. 4 (Statute of Elizabeth or Statute of Charitable Uses), preamble.

25 Vancouver Society of Immigrant and Visible Minority Women v MNR, [1999] 1 SCR 10 at 202, [1999] SCJ no 5 (QL). 26 Ibid. 
Canadian non-profits receive $51 \%$ of their income from government grants and contracts, while $39 \%$ comes from fees for service and $10 \%$ from philanthropic sources, including personal giving. ${ }^{27}$ According to a comparative study of the non-profit sector by Hall et al., the dependence of Canadian non-profits on government funding is exceeded only by the Western European social welfare states, but is much greater than in other Anglo-Saxon countries. ${ }^{28}$ Due to the nature of our federal system, organizations can seek funding from federal, provincial, and municipal governments. As the provinces have jurisdiction over health, education, and most social services, most organizations are primarily dependent on provincial government grants, which mostly come in the form of contracts for services. ${ }^{29}$ It may be surprising, then, that the focus of the frustration over the lack of CSO funding is focused on the federal level government, but this is so for at least two reasons. Firstly, the regulation of charities is a matter of federal law and policy, therefore it follows that lobbying related to the support of CSOs would happen on this level. The government has undermined some CSOs, for example, by characterizing public interest and policy work as too "political" (as opposed to "charitable"), thus resulting in the revocation of the charitable status of organizations under the Income Tax Act. Others have been defunded after the federal government labelled them as being under the influence of foreign agents who are working against Canada's interests. ${ }^{30}$ Secondly, in contrast to the majority of organizations, those categorized as "law, policy, and advocacy" and "international" organizations receive a much larger share of their incomes from the federal government. ${ }^{31}$ These organizations are much more likely to engage in advocacy activities than service provision, and since their funding is more likely to be grantbased than contract-based, they have more opportunity to devote their resources to this advocacy work.

A charity must devote "substantially all" of its resources to charitable purposes but may devote part of its resources to acceptable political activities, ${ }^{32}$ or advocacy. Acceptable politics are those that are non-partisan, connected to the organization's purpose, and subordinate to the organization's primarily charitable focus. "Substantially all" is not quantified by the Act but is determined by the CRA, which generally expects $90 \%$ or more of the organization's activities to be charitable, meaning $10 \%$ of time and resources can be used for advocacy. ${ }^{33}$ Recognizing the disproportionate impact that this requirement has on the capacity of smaller charities to engage in advocacy and the lack of certainty about the allowable levels of advocacy, the CRA released a policy statement clarifying the policy on political activities in 2003. This document increased the freedom of smaller charities to participate in advocacy

27 Ibid at 16.

28 The countries surveyed in the "welfare partnership" group include Austria, Belgium, France, Germany, Ireland, Israel, Italy, the Netherlands, and Spain. The researchers found that nonprofits in this group depend on government for an average of $57 \%$ of their revenues. Canadian nonprofits are less dependent on government funding than this group but more dependent than the Anglo-Saxon group (United Kingdom, United States, Australia, 36\%), the "Asian industrialized" group (Japan and South Korea; 35\%), the Eastern European group (Czech Republic, Hungary, Poland, Romania, Slovakia; 32\%), the Nordic group (Finland, Norway, and Sweden; 31\%), the African group (Kenya, South Africa, Tanzania, Uganda), and the Latin American group (Argentina, Brazil, Colombia, Mexico; 15\%). Hall et al, supra note 8 at 19.

29 Chris Miller, "Canadian Non-profits in Crisis: the Need for Reform" (1998) 32:4 Social Policy \& Administration at 406.

30 Voices-Voix, "Submission to the UN Periodic Review" (7 October 2012), online: Voices-Voix <http://voicesvoix.ca/sites/voices-voix.ca/files/upr_submission_voices-voix.pdf $>$ at 2 .

31 Hall et al, supra note 8 at 26.

32 Income Tax Act, RSC 1985, c 1 (5th Supp), s 149.1(6.1), and (6.2).

33 Political Activities Policy, supra note 23 at 9. 
by creating a sliding scale for smaller organizations, which may now devote up to $20 \%$ of their resources to political activities. ${ }^{34}$

The Canadian civil society experience is one characterized by contradictions. Rathgeb and Smith note that while Canada has the second largest civil society sector in the world in terms of paid employees, it is barely a significant voice or topic in national political and policy discussions. ${ }^{35}$ Elswhere, it has been suggested that the tax policy governing Canada's charities has led to an "advocacy chill."36 In this view, organizations have begun to censor themselves, by either moderating their statements or remaining completely silent on controversial issues, to avoid the reproach of the charity regulators. ${ }^{37}$ Some even identify the CRA regulations as the reason for Canadian civil society's relatively limited impact in decision-making channels. ${ }^{38}$ While self-regulation is a powerful phenomenon, it would be a mistake to blame the limited capacity of Canadian CSOs to act as social justice advocates entirely on federal law. Statistics Canada found that many charities were unaware of their rights to participate in political activities, many censoring themselves because of the mistaken belief that there is an absolute ban on political activity. ${ }^{39}$ In the $2004-5$ fiscal year, the average expenditure of a charity on political activities was only 0.02 per cent of revenue. ${ }^{40}$ The largest share of charities, those with revenues from $\$ 100,000$ to $\$ 200,000$, only spend 0.15 per cent of their revenues on political activities.

The fact that Canadian charities do not engage in political activities at a level even close to the allowable limits suggests that the impuissance of CSOs as political actors in Canada cannot be explained by restrictive federal policies alone. Nor can it be blamed entirely on the former Conservative government, even though the sector had come under direct attack from members of its Cabinet in recent years. ${ }^{41}$ These decisions have certainly contributed to the CSOs capacity deficit, but they must be considered as part of a broader historical narrative, in which government support for civil society action has reflected the shift in the government's agenda and interests. Equally as important to consider is the fact that when we speak of a civil society sector, we assume that the myriad organizations working within it share a common ethos, when their visions of how they should relate to the state are quite often at odds.

34 Ibid.

35 Susan D Phillips \& Steven Rathgeb Smith, "Between Governance and Regulation: Evolving Government-third Sector Relationships" in Susan D Phillips and Steven Rathgeb Smith, eds, Governance and Regulation in the Third Sector: International Perspectives (New York: Routledge, 2011) 1 at 19-20.

36 Blake Bromley, "Does the Government Have in Hand in Which Charities get Audited?", Huffington Post (13 September 2014) online: $<$ http://www.huffingtonpost.ca $>$.

37 Susan D Phillips, "Canada: Civic Society Under Neglect" (2010) 23:1 The Philanthropist 65 at 69.

38 Ibid.

39 Peter Elson, High Ideals and Noble Intentions: Voluntary Sector-Government Relations in Canada (Toronto: University of Toronto Press, 2011) at 144.

$40 \quad$ Ibid at 82.

41 In November 2012, Minister for International Cooperation Julian Fantino was quoted as saying "I think some people believe that [the Canadian International Development Agency] only exists to keep NGOs afloat and to keep them working and that we will fund them for life," he said. "It's not going to be the case." Kim Mackrael, "Canada's foreign aid doesn't exist to keep NGOs afloat", The Globe and Mail (28 November 2012) online: The Globe and Mail $<$ http://www.theglobeandmail.com>. 


\section{Consensus or Conflict?}

In order to truly appreciate the specific characteristics of Canadian CSOs, it important to consider the competing visions of civil society that exist in the literature. The differences are not purely academic; these divergent understandings of civil society are played out in the history of the civil society movement in Canada and can provide us with inventive ways to imagine the role and identity of the sector into the future.

The tacit agreement on the state's responsibility to create institutional channels and provide material resources and a supporting environment for CSOs to participate in governance that emerged in Canada can be described as a consensus-based model of civil society. This is the model privileged in international policy circles, for example CIVICUS's enabling environment framework ${ }^{42}$ and the writings of cosmopolitan democrats like Mary Caldor. ${ }^{43}$ The theoretical underpinnings of this approach relate to Jürgen Habermas' writings on the civil society construct. Habermas considered humans to be fundamentally democratic beings and his understanding of civil society is informed by his desire to establish the foundational requirements for democratic institutions. ${ }^{44}$ The democratic legitimacy of these institutions is established through public dialogue, in which the argumentation of participants with disparate interests eventually brings them to a shared idea of how a good society should look. ${ }^{45}$ The consensus approach is also at work in the theory of networked governance, which argues that the traditional governance model, in which governments are responsible for creating and executing policies and programs, can no longer accurately describe the ways in which modern governance is carried out. ${ }^{46}$ In the place of this hierarchical model is one based on interdependent networks of policymaking and service delivery carried out by both state and non-state actors. The networked approach to governance has been trumpeted by some scholars as having the potential to enhance liberal democracy with its incorporation of a wider range of stakeholders into decision-making channels. ${ }^{47}$

In contrast with the consensus-based model are the approaches that understand civil society as rooted in dissent and struggle. These formulations are premised on a more pluralistic distribution of power than in the consensus-based approaches outlined above. In Gramscian thought, the civil society sphere stands in mutually reinforcing tension with political society (state/government). ${ }^{48}$ As the space where ideology is formed and contested, civil society could replicate hegemony without the need for state coercion, a process called "manufactured consent." However, Gramsci embraces the potential of civil society to fight against domination and challenge harmful ideology through the adoption of counterhegemonic practices. For Foucault, power is imbued in all social relations and institutions, and from this view, the

42 CIVICUS, "CIVICUS' 2013 Enabling Environment Index" (2013), online: Civicus <www.civicus.org>.

43 Mary Kaldor, Global Civil Society: An Answer to War (Cambridge: Polity Press, 2003).

44 Bent Flyvbjerg, "Habermas and Foucault: Thinkers for Civil Society?" (1998) 49:2 British Journal of Sociology 210 at 211.

$45 \quad$ Ibid at 212.

46 Rachel Laforest, "Governance and the voluntary sector: rethinking the contours of advocacy" (2004) 30 International Journal of Canadian Studies 185 at 187.

47 Peter Bogason \& Juliet A Musso, "The Democratic Prospects of Network Governance" (2006) 36:1 The American Review of Public Administration 3.

48 Joseph A Buttigieg, "Gramsci on Civil Society" (1995) 22:3 Boundary 2, 1 at 6. 
history of society can be told as many stories of power and conflict. ${ }^{49}$ In this context, "conflict" is not a dirty word: it is through conflict that social values and goals are negotiated and established. ${ }^{50}$ Tilly and Tarrow's theory of contentious politics describes the ways that despite political constraints, civil society actors and social movements at various points in history have used an array of confrontational mechanisms to struggle for social change. ${ }^{51}$ As we begin our overview of the historical development of the civil society sector in Canada, keep in mind this tension between consensus and conflict as the proper approach to public participation.

\section{RETHINKING HISTORIES: A RECORD OF SHIFTING GROUND FOR CANADIAN CSOs}

According to some accounts from members and observers of the Canadian civil society sector, the climate of financial and regulatory insecurity for CSOs is a relatively recent development, a chill created deliberately by Stephen Harper's Conservatives since the election of its first minority government in $2006{ }^{52}$ It is true that this government has been surprisingly candid about its lack of will to support the activities of institutions that oppose its socio-economic and political agenda. Responding to a question about the federal funding of environmental groups opposed to oil sands development in 2012, Prime Minister Harper stated: "If it's the case that we're spending on organizations that are doing things contrary to government policy, I think that it is an inappropriate use of taxpayer money and we will look to eliminate it." ${ }^{, 33}$ Sure enough, the 2012 budget earmarked $\$ 8$ million in funding to bolster the auditing capacity of the CRA, specifically to identify charities breaching the regulations on political activities. ${ }^{54}$ The most prominent public examples of the targets of this new auditing push were seven environmental CSOs, many of which had received federal funding for years without encountering issues. The organizations and their defenders suspect that they have been targeted for audits not because of reasonably founded doubts about their accountability but because they were all prominent actors in the opposition to the development of the Alberta tar sands. ${ }^{55}$ In addition to cutting funds to organizations whose mandates run counter to government policy, commentators have noted that the cuts have extended to groups that "give voice to Canadians" more generally. ${ }^{56}$ Some of the core cuts were delivered to programs that had been originally established as a way for the federal government to protect

49 See for e.g. Michel Foucault, Discipline and Punish: The Birth of the Prison, trans. Alan Sheridan (Harmondsworth: Penguin Books, 1977); Michel Foucault, Power/Knowledge: Selected Interviews and Other Writings, Colin Gordon (ed) (New York: Pantheon, 1980); Michel Foucault, "How is Power Exercised?" in Hubert L. Dreyfus and Paul Rabinow (eds), Michel Foucault: Beyond Structuralism and Hermeneutics (Chicago: University of Chicago Press, 1983).

51 Charles Tilly \& Sidney Tarrow, Contentious Politics (Oxford: Oxford University Press, 2006).

52 See for e.g. Laverdière, supra note 1, and Tara M Collins \& Landon Pearson, "The Role and Impact of Civil Society upon Child Rights in Canada" (2011) 23:4 The Philanthropist 451 at 453n.

53 Daniel Proussalidis, "Taxpayers funding anti-oilsands activists" Toronto Sun (7 June 2012) online: $<$ www.torontosun.com>.

54 Evan Solomon \&Kristen Everson, "7 Environmental charities face Canada Revenue Agency audits: Charities fear they may lose charitable status", CBC News (6 February 2014) online: $\mathrm{CBC}<$ www.cbc.ca/news $>$.

55 Ibid.

56 Trish Hennesy, “Chill Effect: Harper's Cold War on Freedom of Speech” in Teresa Healy, ed, The Harper Record (Ottawa: Canadian Centre for Policy Alternatives, 2008) at 41. 
human rights and ensure access to justice, such as the Court Challenges Program, Status of Women Canada, and Rights \& Democracy. ${ }^{57}$

Despite the multifaceted nature of the analysis of civil society, ${ }^{58}$ the question of funding seemed to predominate the popular discourse around civil society in Canada recently. To be sure, there is significant media attention given to other incursions against public participation, notably the violent repression of peaceful protests witnessed in the responses to popular mobilization against the Toronto G20 Summit and tuition fee hikes in Quebec. ${ }^{59}$ Such discussions are often related to broader questions about the respect for Charter freedoms and international human rights standards. In contrast, defunding is a policy decision which does not have the same legal protection as the rights to expression and assembly, but fears about the perceived threats to the future of the CSO sector, by way of defunding, has led some to condemn the practice as an affront to Canadian democracy. ${ }^{60}$

It is important to look closely at this claim, as it involves two charges that must be distinguished from each other. The first is the idea of the government using bureaucratic means to undermine the ability of CSOs to work, and threaten their existence in a politicized manner. There is cause for serious concern when the decisions of federal granting institutions are overridden by members of the executive, as in the case of KAIROS, an organization that lost funding after the government went after groups it considered "anti-Israel."61 Similarly, when the oversight mechanisms of an organization are being applied only to a certain class of organizations, as in the case of the seven environmental charities targeted for auditing, a case can be made that these decisions violate the principles of procedural fairness and indicate a witchhunt based on political ideology.

When considering such cases, it is fair for organizations or individuals to decry these events as threats to democratic governance. However, the problem arises when the issue of the funding and defunding of CSOs is conflated with that of state funding for CSOs in general. Even though many CSOs have steadily secured access to federal government grants for decades, the fact that the government may be withholding funding from their organizations is not necessarily undemocratic in itself. We argue that it

57 Ibid; CBC News, "Troubled Rights and Democracy organization to be closed", (3 April 2012) online: CBC

$<$ http://www.cbc.ca/news/politics/troubled-rights-and-democracy-agency-to-be-closed-1.1185276>.

58 For example, CIVICUS' newly developed Enabling Environment (EE) Index is a leading evaluation tool that measures the combination of socioeconomic, sociocultural, and governance indicators to make an assessment of the capacity of civil society in a given country. Each dimension has sub-dimensions: the socioeconomic environment evaluates education, communications, equity, and gender equality; the sociocultural environment measures propensity to participate, tolerance, trust, and solidarity; and the governance environment is made up of the civil society infrastructure, policy dialogue, corruption, NGO legal framework, rule of law, and a range of political and civil rights. The EE Index replaced CIVICUS' previous model, the Civil Society Index or Civil Society Diamond, which based its evaluation on the structure of civil society, the external environment in which civil society functions, the values practiced by civil society actors, and the impact of activities pursued by civil society actors. See Lorenzo Fioramenti, "A methodological note on the CIVICUS' Civil Society Enabling Environment Index (EE Index)”, CIVICUS (2013) at 5.

59 See for e.g. the police response to protests during the 2010 G-20 Summit in Toronto, Gerry McNeilly, Policing the right to protest: G20 systemic review report, (2012) online: Office of the Independent Police Review Director

$<$ http://www.oiprd.on.ca/EN/PDFs/G20-Systemic-Review-2012 E.pdf $>$; and the police response to the wave of student protests in Québec in 2012: Rapport: Commission spéciale d'examen des événements du printemps 2012, (2014) online: Government of Quebec < http://www.securitepublique.gouv.qc.ca/fileadmin/Documents/police/publications/rapport_CSEEP2012/rapport_CSEP2012.pdf $>$.

60 Caplan, supra note 10.

61 Mackrael, supra note 6. 
is the result of a particular and relatively recent history that Canadians have come to understand civil society as a state-supported sector of non-profit organizations. This section presents an overview of the development of the Canadian CSO sector from its roots in the nascent welfare state until a key moment in the CSO-government relationship in late 1990s/early 2000s. This discussion of history is undertaken to establish two ideas: first, that the contemporary shape of the civil society space is historically contingent; and second, that there has never been a "golden era" for Canadian CSOs. We hope to demonstrate that the scale and nature of the political opportunities and resources granted to organizations by the government is perpetually negotiated and renegotiated. Equally as important, we will show that organizations are not passive recipients of policy dictates from decision-makers. Even within the constraints of the opportunity structure for non-state action created by the state, organizations and their leaders make rational calculations and choose courses of actions that have implications for their own work and the sector as a whole.

\section{A. CSOs Carve a Space in the Mixed Economy of Welfare (1960-1990)}

The sphere that we consider the civil society sector today is but one of a range of institutional products of the Canadian welfare state. The welfare state was consolidated over the course of several decades, the result of successive policy decisions made with the goal of ensuring that all Canadians could enjoy a basic standard of living, without respect to differences in income. Between World War II and the late 1970s, the package of public services and protections that Canadians have come to expect was systematically solidified. ${ }^{62}$ A series of government decisions, sometimes undertaken reluctantly, were made to transition Canada from a residual welfare state, which focused on providing assistance only to the poorest members of society, to a universalist system in the areas deemed to be basic needs (health care, education, employment, and social transfer). The consensus of Canadians around this idea, that government should be and was capable of addressing social welfare issues, propelled the expansion of the welfare state in the postwar decades. By the late 1960s, the core of this system was in place and the trend was "one of expansion with some tinkering at the margins." 63

Canada remains a welfare state, albeit one of a relatively liberal character, rather than a socialdemocratic welfare state. ${ }^{64}$ In contrast to the universalist governance packages of many northern and western European countries, in which access to social benefits and services is granted on the basis of citizenship, the Canadian model privileges the market-based allocation and private provision of resources in which the state only intervenes "to ameliorate poverty and provide for basic needs, largely on a means-tested basis." "65 For this reason, Valverde doubts the usefulness of the very idea of "the emergence of the welfare state," and suggests that it is more accurate to speak of a "mixed social economy" instead. ${ }^{66}$ Known also as a mixed economy of welfare, this understanding of Canadian society is based on the reality of how individual and family livelihoods are sustained in Canada rather than

62 Raymond B Blake, Penny Bryden \& J Frank Strain, "Part One: Understanding Change" in Raymond B Blake, Penny Bryden \& J Frank Strain, eds, The Welfare State in Canada: Past, Present and Future (Concord: Irwin Publishing, 1997) 1 at 1.

63 Ibid.

64 Emanuele Ferragina \&Martin Seeleib-Kaiser, "Welfare Regime Debate: Past, Present, Futures?” (2011) 39:4 Policy \& Politics 583 at 584.

65 Ibid.

66 Valverde, supra note 22. 
political visions of the state's role. This reality is that most Canadians' wellbeing is sustained through permutations of "service provision by governments, families, charities and other non-profits (and to an increasing degree, for-profits), the specific mix of responsibilities varying in different components of the welfare state." ${ }^{, 67}$

Both members and observers of the sector frequently describe service-providing CSOs as filling a gap in the wake of the retreat of the welfare state. However, thinking of the development of the Canadian state as a mixed economy of welfare urges us to acquire a more complicated understanding of the public and the private, or the state and non-state sectors. The federal government has long provided voluntary organizations with financial assistance in exchange for providing social welfare services; there is evidence that even as far back as the first decade of the $20^{\text {th }}$ century, organizations were receiving grants on a case-by-case basis. ${ }^{68}$ Valverde argues that the historical importance of this model is obscured by the focus on publicly funded services that interact with individuals through direct transfers, even though private organizations were receiving government funding from provincial governments to manage institutions like "poorhouses" and "asylums" as far back as the Victorian era, long before those governments began to provide direct payments to individuals in the interwar period. ${ }^{69}$ As the package of statutory services expanded for provinces, the financial allocations of the government to the voluntary sector also grew, most notably in the form of core funding. ${ }^{70}$ Core funding refers to financial resources granted to organizations that is not attached to a particular program or project, which allows them to support day-to-day operations. Core funding gave CSOs the latitude to pursue projects beyond their contracted services, notably advocacy and lobbying activities.

Discussions of the history of the welfare state often focus on top agenda items like health care and education, but the growth and institutionalization of the civil society sector during these years was a crucial, albeit a less acclaimed part of the history. Laforest's account of this period explains that the political climate in 1960s Canada created opportunities for citizens to begin to convene around representational issues, as the government responded to the national unity crises of the era by encouraging the mobilization of organizations around various identities, including organizations working on official language minorities, multiculturalism, and women's issues. ${ }^{71}$ The expansion of the Canadian CSO sector took place in the broader context of what has been called the "global associational revolution," which describes the proliferation of social justice organizations across the world throughout the 1970s and 80s. ${ }^{72}$ From the increasing intolerability of communist and authoritarian regimes in the Soviet Union, to the extreme income inequality produced by neoliberal governments in Latin America, the boom in civic associations was a response to the growing perception that state attempts to ameliorate social problems were not only inadequate but in fact worsening social wellbeing. During the 1970s and 1980s, civil society groups in Canada began to gain the official recognition and access to policymaking forums that reached its apex in the 1990s, when "national voluntary organizations had matured into

67 Susan D Phillips, "Dual Restructuring: Civil Society and the Welfare State in Canada, 1985-2005" (2012) 25:2 British Journal of Canadian Studies 161 at 165.

68 Rachel LaForest, Voluntary Sector Organizations and the State: Building New Relations (Vancouver: University of British Columbia Press, 2011) at 27; Miller, supra note 29 at 406.

69 Valverde, supra note 22 at 37.

70 LaForest, supra note 68 at 27.

$71 \quad$ Ibid at 28.

72 Lester M Salamon, "The Rise of the Nonprofit Sector" (1994) 73 Foreign Affairs 4. 
strong advocates on many policy fronts." ${ }^{, 3}$ This period has been "nostalgically portrayed as a golden era for civil society representation in Canada, characterized by citizen activism, networks of supportive allies, and regular opportunities to be consulted in policy making." ${ }^{74}$ By the mid-1980s, the sphere was large but did not present a united front in the political or policy arena, as most organizations did not yet understand themselves as part of a common sector with the potential to organize on a collective basis. ${ }^{75}$

\section{B. Redistributing Responsibilities for Social Welfare (1990-1995)}

By the late 1980s, it was becoming clear that the pattern of expansion of the state welfare provisions was waning. What we have now come to recognize as the retreat of the postwar welfare state, and the emergence of the Washington Consensus, ${ }^{76}$ was beginning to become apparent in Western industrialized economies. Like their counterparts in the United Kingdom and the United States, successive Canadian governments pursued strategies of "fiscal restraint," in which public spending on the welfare state program came under attack..$^{77}$ The erosion in funding to health care, social assistance, income support, unemployment insurance, postsecondary education, cultural and artistic programs, development aid and environmental protection that Canadian CSOs and citizens deplore today began three decades ago. ${ }^{78}$ In its place, a market-driven imperative, bolstered by deregulation of industry and trade liberalization, fuelled the growth of the popular idea that bloated, inefficient, and inept governments had failed to eliminate social inequities. ${ }^{79}$ Private initiatives, not only corporate ones, but also those of the individual citizen and family unit, became privileged as the most effective and importantly, the most legitimate and just mode of improving general social wellbeing.

Aiming to reduce the size of government, the Liberal majority government launched a sweeping evaluation of its departments and policies, called the Program Review, in 1994. With its stated goal to determine "the core role of government," Laforest suggests that the Program Review had three major implications for the voluntary sector. Firstly, it brought about the creation of new mechanisms for service delivery, such as contracting and government-CSO partnerships. Secondly, the Program Review was part of the government's broader discursive shift with respect to the voluntary sector. CSOs and "volunteers" came to be seen as an "untapped resource" that could deliver services in a more costeffective manner than government. Lastly, a series of institutional changes in the ways that serviceproviding government departments related to the voluntary sector had lasting impacts on the CSO sector. ${ }^{80}$ The Program Review could be described as the institutionalization of a shift in the theory and practice of governance in Canada and a process that sought to shrink and streamline government by

\footnotetext{
73 Laforest, supra note 68 at 28.

74 Susan D Phillips, "Restructuring Civil Society: Muting the Politics of Redistribution" in Keith Banting \& John Myles, eds, Inequality and the Fading of Redistributive Politics (Vancouver: University of British Columbia Press, 2013) 116 at 119 .

75 Ibid.

76 Dani Rodrik, “Goodbye Washington Consensus, Hello Washington Confusion?” (2006) 44 Journal of Economic Literature 973.

77 Ernie Lightman \&Allan Irving, "Restructuring Canada's welfare state” (1991) 20:1 Journal of Social Policy 65.

78 Andrew C Parkin, "Social Justice Movements and the Crisis of the Welfare State: Observations from the Halifax People's Summit" in Blake, Bryden \& Strain, supra note 62, 36.

79 Pat Armstrong, "The Welfare State as History" in Blake, Bryden \& Strain, supra note 62, 53.

80 Laforest, supra note 68 at 31-2.
} 
adopting private sector management styles, separating policy making from the implementation of programs, and improving the quality of service delivery, often through the use of private sector partners. ${ }^{81}$ Beyond policy changes, there were also immediate material effects: $\$ 51$ billion was cut from federal social programs between 1990 and $1996 .{ }^{82}$ Many members of the CSO sector believed that the return of the Liberals to power implied a reversal in the 1980s cuts to the civil society sector by the Mulroney government. Instead, CSOs were met with a 20 percent cut in grant funding for the 1995/1996 fiscal year, followed by cuts between 10 and 25 percent for the next three years. ${ }^{83}$

\section{Renegotiating the CSO-government Relationship (1996-2000)}

After the Program Review, contracting became the preferred funding model of the federal government. As access to core funding became increasingly scarce, the government increased the number of contracts with CSOs. This funding model specified the services to be carried out and the obligations of each party in relation to the contract. ${ }^{84}$ The move towards contract culture was followed by the espousal of "results-based management," under which funding is contingent on the ability of contracted organizations to "link their use of resources to established performance indicators and effectiveness measures, which were tracked in order to improve transparency, accountability, effectiveness, and efficiency." 85 These problems were compounded by changes to the regulations governing non-profit organizations that would shift the balance of power in favour of the government even further. Charitable status became crucial for CSOs for several reasons: it allows the organization to receive donations, eases the ability to enter in relationships with other private and public organizations, and generally confers legitimacy on CSOs. ${ }^{86}$ Moreover, this policy shift reinforced the perception of CSOs as primarily charitable organizations, as opposed to valuable sources of policy research or alternative voices in public debate.

Another important change was discursive one, which has had more lasting effects than any modifications to the policy and legal space governing CSO activity. Over the course of the 1990s, civil society organizations saw a shift in public perception of their activity from an important voice in a plural democracy to an idea of partisan, narrowly-focused "special interest groups." Still wanting the legitimacy conferred by public participation and consultation, the government began to privilege the voice of the "ordinary citizen," instead of organizations working on representative politics. ${ }^{87}$ This signalled a profound shift from the understanding of the civil society sector that had developed by the 1980s, in which institutionalized access to policymaking was set up around organized interests. The political message of the day was that the most legitimate representation was from the "tax-paying, selfreliant, independent individual [and that] the special claim, need, or interest is a drain on legitimate state

81 Gene Swimmer, ed, How Ottawa Spends 1997-98, Seeing Red: A Liberal Report Card (Ottawa: Carleton University Press, 1998) at 4, as cited in Laforest, supra note 68 at 32.

82 Phillips, supra note 67 at 161.

83 Miller, supra note 29 at 409.

84 Laforest, supra note 68 at 36.

85 Ibid at 37.

86 Ibid at 39

87 Phillips, supra note 65 at 170. 
resources, an impediment to a global free market, an excuse to avoiding individual responsibility." ${ }^{88} \mathrm{We}$ see that the dismissal of civil society groups as unrepresentative, particularized interests did not begin with Harper's Conservatives in 2006.

Recognizing the need to act collaboratively to face the changes to the civil society climate, a group of leading non-profit organizations formed a working group called the Voluntary Sector Roundtable [VSR] in 1997. The VSR engaged a panel of six voluntary sector insiders and a prominent chair, former New Democratic Party leader Ed Broadbent, to respond to public perceptions of the accountability and governance deficits in the CSO sector. The panel published a report that addressed issues of governance and stewardship, program outcomes, fundraising, and capacity building. ${ }^{89}$ The capacity building agenda was important, as the goal of developing capacity was primarily related to the ability to strengthen the relationship with government ${ }^{90}$ (as opposed to developing lobbying or policy research capacity). The VSR was the first high-level attempt for prominent members of the civil society sector to begin to understand their situations and interests as common, but it suffered some representational problems. The process was primarily led by charity leaders and included virtually no representative from social movements and advocacy organizations, who formed the base of the CSO sector in the preceding decade. $^{91}$

In 1999, the Liberal government's Voluntary Sector Task Force created a process called the Joint Tables, in which working groups with equal government and voluntary sector representation (including the members of the VSR) were established. Mandated to develop responses to problems related to statesector interaction (including building relationships, strengthening capacity, and improving the regulatory framework), the three Joint Table sessions resulted in the Working Together report that recommended, among other things, the establishment of a framework agreement between the government and the voluntary sector. ${ }^{92}$ This idea was inspired by the UK's CSO-government "Compacts," established in the mid-1990s, which were later were styled in Canada as "Accords." The idea of the Compacts or Accords were to establish the terms of interaction between the sectors; they placed an emphasis on recognizing the independence of the voluntary sector and the right of its organizations to challenge the government's laws or policies without funding repercussions. ${ }^{93}$ The signing of the Accord was the first phase of the Voluntary Sector Initiative [VSI], launched by the Chrétien government in 2000. The VSI had the same

88 Linda Trimble, "What's So 'Special' about Human Rights?” (Paper presented to Citizenship 2020: Assuming

Responsibility for Our Future, McGill University, 2000), as cited in Laforest, supra note 68 at 47.

89 Panel on Accountability and Governance in the Voluntary Sector, Building on Strength: Improving Governance and Accountability in Canada's Voluntary Sector (1997) online: Voluntary Sector Roundtable $<$ http://www.creativetrust.ca/ $>$ [VSR Final Report].

90 Kathy L Brock, "Policy Windows and Policy Failures: Using Kingdon to Explain the Later Life Cycle of the Voluntary Sector Initiative," (May 2008) Draft Paper Presented to Annual Canadian Political Science Association meetings at the University of British Columbia, June 2008, at 7.

91 Phillips, supra note 65 at 173.

92 Peter R Elson, “A Short History of Voluntary Sector-government Relations in Canada” (2009) 21:1 The Philanthropist 36 at 55 .

93 Brock, supra note 90 at 7. For the UK Compacts, see Home Office, The Compact on Relations between Government and the Voluntary/Community Sector (1998) and the newly negotiated version at Compact: the agreement between government and the community sector (2010), online: Department for Work and Pensions <https://www.gov.uk/ >. For the Canadian Accord, see An accord between the Government of Canada and the voluntary sector (2001), online: Privy Council Office, <http://publications.gc.ca/ $>$. 
goal as the Joint Tables, only fortified by a five year, $\$ 95$ million commitment allocated for the Initiative to draft the Accord, develop IT and information management systems, raise public awareness, strengthen capacity, and tackle regulatory issues. ${ }^{94}$

The VSI placed the same emphasis on charities as the VSR, which further contributed to the perception of CSOs as service providers, and again marginalizing advocacy CSOs. ${ }^{95}$ Many voluntary sector representatives reacted negatively to the announcement of the VSI as they were not consulted in the lead-up and nearly a third of the funds promised would go directly to federal government departments. ${ }^{96}$ In a show of force, voluntary sector leaders left the VSI press conference in protest and put forth new recommendations for the budget. Many of the recommendations were heeded and several were actually implemented by the government. ${ }^{97}$ Despite this move, the VSI continued to be led by the government. The leaders of the voluntary sector made a deliberate decision to work from within, "routing its claims through state institutions." also attempting to develop a stronger and more collaborative relationship with government was a tenuous position for the leaders of the voluntary sector. The resources required for this rapprochement with government became overwhelming for many organizations, which saw their abilities to engage in successful advocacy diminish in turn. ${ }^{9}$

The purpose of this historical analysis is to demonstrate that while civil society organizations play an important role in Canadian governance, the perceived specificity of their role and engagement is at best simplistic. The anatomy of the civil society sector has been shaped by a series of rationally calculated decisions taken by governments and the sector alike. The issue of federal government funding cannot be examined in isolation from the broader question of the relationship between civil society and the government. This includes not only the provision of grants for operations or contracting for services, but also other points of cooperation, such as the institutionalization of access to decision-making for civil society actors. To date, the issue of "relationship building" with the state has been the one of the priority items of national-scale CSO action. This preoccupation gives us some insight to formulate responses for those frustrated with the potential of CSOs to thrive as entities and to act as meaningful political players.

\section{CSO AGENCY IN THE MAINSTREAMING OF CIVIL SOCIETY}

The previous section attempted to analyze political and economic influences nationally and internationally which have shaped Canadian CSOs. To best understand and respond to the challenges facing the CSO sector, we must note that as in Elson's words, the relationship between this country's federal government and its voluntary organizations has long been weak and/or turbulent; rarely has it been mutually supportive and productive. ${ }^{\prime 100}$ By the early 2000s, the deterioration of the funding relationship and the increasingly burdensome reporting requirements needed to obtain grants and

\footnotetext{
Laforest, supra note 68 at 78.

Phillips, supra note 65 at 173.

Laforest, supra note 68 at 78-79.

Ibid at 79.

Ibid at 80 .

Ibid.

Elson, supra note 39 at 3.
} 
contracts had strained the civil society sector to what many considered a crisis point. ${ }^{101}$ To balance their books and continue to act as functional organizations, CSOs were forced to reduce expenditures, let go of staff, and increasingly rely on revenues from service provision contracts and earned income. ${ }^{102} \mathrm{~A}$ national survey of key civil society representatives in 2001 found that the majority believed that the lack of funding for non-profits was having an impact on the sustainability of their work, and most claimed to know of at least some organizations that had been forced to terminate their operations due to lack of funding during the past year. ${ }^{103}$ The consequences of the increasing scarcity of funding also had more insidious implications: many CSOs began to self-censor by refraining from taking potentially controversial policy positions and opting for more moderate projects and methods so as to appease state and private funders. ${ }^{104}$

The previous section presented an overview of this history to demonstrate that the relationship between (and the distinction between) civil society and the state is dynamic and contingent. We sought to demonstrate that the idea that there was a "golden era" from which we are only recently departing does not hold water historically; there were as many years of decline in civil society support as years of plenty. Nonetheless, we appreciate the limitations of presenting facts and figures in response to the unquantifiable perception of those who work or have worked in the NGO sector. In the words of one veteran CSO worker, "there was a feeling that [funding] would never dry up. It was considered part of the social contract of this country. ${ }^{" 105}$ For many of these individuals and their organizations, government funding was taken for granted and considered a particular virtue of the Canadian welfare state, in contrast with the primarily privately funded US non-profit sector.

Still, the changing political landscape alone cannot explain the relatively limited potential of Canadian CSOs to act as powerful advocates and policy innovators. The interdependence that we observe today was not accidental. The leading organizations and individuals in the civil society sector made choices that were rational calculations based on the existing opportunities and the perception of the benefits that would flow from these choices. During the periods of government generosity, many mainstream CSOs uncritically embraced the government, resulting in both a situation of dependency and a crisis of identity for organizations conceived as alternatives or challengers to the state. ${ }^{106}$ Moreover, the idea that there was a "social contract" that guaranteed financial and political support to CSOs is not convincing when faced with evidence that the associations of certain groups in Canadian society were never invited to enjoy resources or platforms at decision-making tables. This section discusses the various decisions that the Canadian CSO sector has made in its decision to work within the channels of government and the consequences that flowed from these decisions. Be they strategic political

101 Phillips, supra note 65 at 172.

102 Ibid.

103 Don K Embuldeniya, Exploring the Health, Strength, and Impact of Canada's Civil Society (Toronto: Canadian Centre for Philanthropy, 2001) at 14 online: Imagine Canada <www.imaginecanada.ca $>$.

104 Paul A Pross \& Kernaghan R Webb, "Embedded Regulation: Advocacy and the Federal Regulation of Public Interest Groups" in Kathy L Brock \& Keith G Banting, eds, A Delicate Dance: The Non-profit Sector and Government in Canada (Kingston: McGill-Queen's University Press, 2003); Katherine Scott, Funding matters: The Impact of Canada's New Funding Regime on Non-profit and Voluntary Organizations (Ottawa: Canadian Council on Social Development, 2003); Phillips, supra note 65.

105 Miller, supra note 29 at 408.

106 Ibid at 407. 
calculations or reluctant choices made from a field of undesirable options, they all have consequences that have conditioned the character of CSOs internal and external politics.

\section{A. Insiders and Outsiders}

Why has the Canadian CSO sphere been described as a "bifurcated" sector? ${ }^{107}$ In terms of structure and organization, we can divide the majority of Canadian non-profits into two camps. The first is a small group of large, registered charities that are staffed by paid employees. Working largely in the areas of health, education, and social service provision, these organizations attract the lion's share of government and private funds. They are distinct from the majority of CSOs, which are smaller, more volunteerdependent, and rely on earned income to finance their work. These organizations are more involved in expressive functions rather than services.

The power disparity between different classes of Canadian CSOs is apparent when looking back on the VSI, where important questions of representation and identity were raised even in the initial planning phases. As noted in the previous section, advocacy groups were sidelined and the service-oriented organizations sought to build closer working relationships with government. Consequently, it should have been expected that the beneficiaries of the VSI process were large, mainstream CSOs and national umbrella organizations. ${ }^{108}$ Laforest suggests that "the Canadian experience saw voluntary organizations move quite decisively toward insider roles" and that despite being intended to broaden civic participation, "the opportunity structure favoured by the VSI favoured elite accommodation." 109 There was palatable tension between those perceived as insiders and those who felt that they were outsiders to the process. Those on the outside were often representatives of younger NGOs that were less accustomed to the culture of the VSI, characterized by large meetings and policy rhetoric. Eight of the 19 representatives of participant organizations interviewed by Laforest felt that they were "mere spectators" in the process, watching the larger, national organizations on centre stage. If this is the feeling of organizations that were invited to the table, one can only imagine how smaller NGOs outside of the process must have understood their place in the national civil society discussion.

The representation of Aboriginal and racial and ethnic minority groups in the process was largely tokenistic, as only one organization was invited to represent each of these large and heterogeneous communities. The idea of the VSI was to discuss sectoral issues jointly between civil society representatives and government, but two separate "Reference Groups" were created to represent the Aboriginal and "visible minority" communities, ${ }^{110}$ effectively suggesting that the issues affecting these communities are separate from those affecting society generally, and that their representatives are only worthy of the platform when they are discussing the issues of their specific communities. Organizers claimed that organizations representing these minority groups were "difficult to reach" and as they tended to be smaller entities, lacking in capacity to engage with the VSI process. ${ }^{111}$ Quebecois CSOs were similarly treated as marginal actors in the process, and there was a steady withdrawal of

\footnotetext{
107 Hall et al, supra note 8 at 27.

108 Laforest, supra note 68 at 81 .

109 Ibid.

110 Human Resources and Skills Development Canada, Voluntary Sector Initiative Impact Evaluation: Lessons Learned from the Voluntary Sector Initiative (Ottawa: Government of Canada, 2009) at iii [VSI Final Report].

111 Ibid at xii, xi.
} 
organizations throughout the process as many felt that their goals would be better served in a provincial initiative. ${ }^{12}$ Beyond the sidelining of Aboriginal, Canadians, and Quebecois organizations, many communities were excluded entirely from the VSI: "while women were selected, no women's groups were represented, nor were poverty groups, nor lesbian and gay groups." 113

Speaking of the VSI, a representative of one of the invited organizations explains the trade-off and the imbalance of power implicated in the process:

Some people thought it was a mistake but you can't say no to 95 million. They were overly optimistic. Again, who's they? It's a critical part of this. It's clear that it was an old guard. The problem was that there did not seem to be a new guard. Some of the more sceptical voices weren't there yet. ${ }^{114}$

While the VSI is but one process in the history of Canadian civil society space, it remains a powerful example of the broader pattern of interdependence between the state and civil society sector in Canada since the late 1990s. ${ }^{115}$ When CSO representatives lament the loss of the days when funding was abundant and participation in policy-making platforms was encouraged by government, they are likely to have come from one of the insider organizations. These organizations are more likely to be large, national, charitable in nature, moderate politically, and have close professional and personal ties to decision makers - the old guard. In contrast, organizations that are smaller, grassroots, and that work with minority communities are less likely to complain about the loss of funding and status, because most never enjoyed it in the first place.

\section{B. Professionalization and Privilege in the Nonprofit sector}

As CSOs turned the major focus their activities away from advocacy and organizing and towards policy development and service provision, the composition of their membership also began to look different. Mananzala and Spade paint a portrait of the contemporary CSO that should be familiar to anyone working in or familiar with the sector: organizations with "boards consisting of donors and elite professionals (sometimes with tokenistic membership for the community members who are directly affected by the organization's mission)... Non-profits serving primarily low-income and disproportionately non-White populations are frequently governed almost entirely by White people with college and graduate degrees." ${ }^{116}$ The authors write in the US context but this is likely the image in the mind of the person who described the VSI insiders as the "old guard". The underrepresentation of ethnic minorities and immigrant Canadians in the non-profit labour force and board membership in Canada has been documented in several studies. ${ }^{117}$

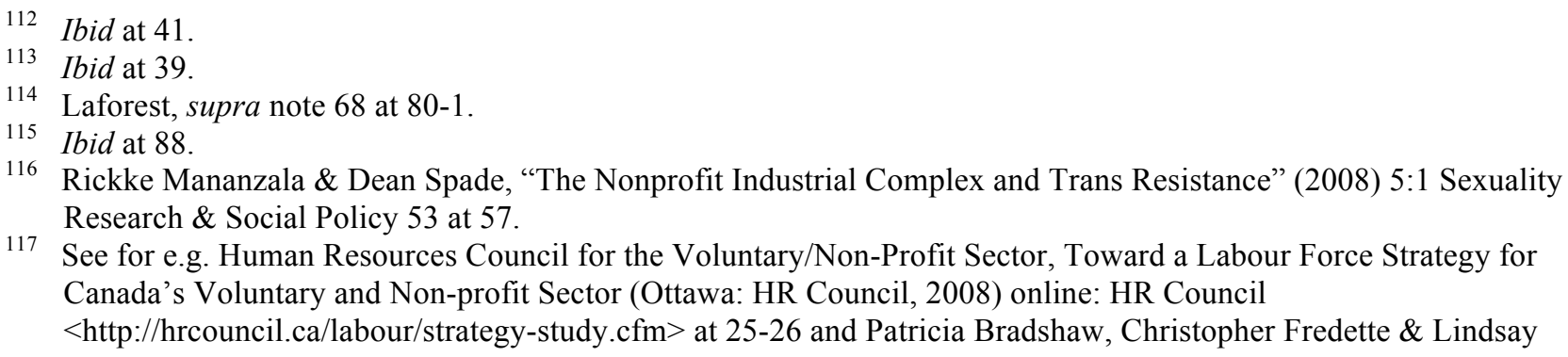


As indigenous and racialized Canadians are twice as likely to live in poverty than white Canadians, ${ }^{118}$ it is particularly egregious when they are absent or underrepresented in organizations that purport to speak on their behalf and provide services to their communities. Beyond representing a serious contradiction for groups with goals related to equity and combatting discrimination, the lack of representation of minorities has real consequences for the effectiveness of policy development and service provision. The inclusion of more diverse voices, beyond the white, middle-class, universityeducated, paid staffer that has become the stereotypical idea of the civil society representative, would make programs and policies much more responsive to the communities they are intended to serve. While racialized Canadians are very involved in civil society efforts as founders and members of ethnicallyspecific organizations, which is an important site of integration for many of these individuals into Canadian society, ${ }^{119}$ the siloing of their efforts in this area means that several "mainstream" CSOs not only miss out on talented individuals but also on potentially productive points of intersectional organizing with these individuals and their groups. ${ }^{120}$

The professionalization of the CSO sector creates problems beyond the representational issues described above. Professionally trained people, with work backgrounds in industries like law and business, do not only bring their expertise, but also managerial styles that are not suited to the social justice sector. CSOs have begun implementing private sector hierarchies and titles; leaders of organizations with social justice goals are increasingly referred to as Chief Executive Officers and Presidents. ${ }^{121}$ Choudry and Shragge suggest that this trend is a result of the belief that "social change is a highly specialized profession best left to strategists, negotiators and policy wonks."122 This phenomenon, that they call the "professionalization of dissent," undermines the capacity and spirit of community organizations as social justice actors, by imbuing their processes with the same logic as those that maintain hierarchies of power and bureaucracy.

\section{From Politics to Rights}

In addition to the changes to the civil society space that serve to widen or constrict the space for CSO action, there has also been a marked displacement in the site of conflict with the state over the past decades. After a comprehensive bill of rights was enshrined in the Canadian Charter of Rights and Freedoms in 1982, the Canadian judiciary expanded the scope of these basic rights to new areas of social interaction over the following decades. ${ }^{123}$ This "Charter Revolution" was not advanced by judges

Sukornyk, "A call to action: diversity on Canadian not-for-profit boards" (2009) Schulich School of Business. For figures on the diversity of the voluntary sector in Toronto specifically, see Wendy Cukier \& Margaret Yap, Diversecity Counts: A Snapshot of Diversity in the Greater Toronto Area (Toronto: The Diversity Institute, 2009) at 21-22.

National Council on Welfare, Poverty Profile: A Snapshot of Racialized Poverty in Canada (Ottawa: National Council on Welfare Reports, 2009).

119 E de Leon et al, Community-based Organizations and Immigrant Integration in the Washington, D.C. Metropolitan Area (Washington, D.C.: The Urban Institute, 2009) as cited in Agnes Meinhard et al, "Civic Participation of Visible Minorities in Canadian Society: The Role of Nonprofit Organizations in Canada's Four Most Diverse Cities" (2011) 1 Centre for Voluntary Sector Studies, Ryerson University, Working Paper Series at 12.

120 Alyssa Clutterbuck, By us, for us": a woman of colour critique of non-profit social justice (2013) [unpublished].

121 Ibid at 7.

122 Aziz Choudry \& Eric Shragge, "Disciplining dissent: NGOs and community organizations" (2011) 8:4 Globalizations 503 at 507.

123 FL Morton, "The Charter Revolution and the Court Party” (1992) 30:3 Osgoode Hall LJ 627. 
alone but was championed by what Morton and Knopff deride as "the Court Party... a loose coalition of feminists, civil libertarians, government lawyers, Supreme Court clerks, law professors, and social activists." ${ }^{124}$ These groups were intimately engaged in the constitutional project, by contributing to the drafting, lobbying, and promotion of the Charter after its adoption. The expansion of the Canadian human rights CSO sector occurred in the context of the global associational revolution and the rise of human rights discourse and the international human rights system in the postwar context. ${ }^{125}$ It also occurred amidst an intensification of global action by Canadian CSOs, as a cross-border solidarity began to emerge among groups that had been historically oppressed or exploited, a trend given the name cosmopolitanism by de Sousa Santos. ${ }^{126}$

Canadian human rights organization proliferated amidst this global trend and saw even greater opportunities for social justice activism with the arrival of the Charter. The Court Challenges Program [CCP] was an important vehicle for the judicial advancement of rights claims. Founded by Pierre Trudeau in 1978, the CCP's initial purpose was to help fund language rights cases but after the Charter came into effect in 1985 its mandate was expanded to fund cases impugning the equality and sex equality sections of the Charter. ${ }^{127}$ Human rights litigation is a lengthy, costly endeavour and the Program provided the resources to fund test cases that secured several minority rights, including the right of people accused of crimes to be tried in their own language; official language minorities' right to govern their own school boards and their right to higher education in their language; equality protection for same-sex couples; the right of Aboriginal Canadians living off-reserve to vote in band elections; the protection of employment insurance benefits for seniors; pay equity cases for women; and the right of disabled people to accessible trains. ${ }^{128}$ Such litigation, and funding for it, was essential to give force and life to the new constitution, by giving individuals meaningful access to the courts to obtain redress for harms suffered to them and also by forcing the judiciary to elucidate and develop the scope of the rights enumerated.

The Mulroney government's elimination of the CCP's funding in 1992 produced widespread public opposition and Jean Chrétien's Liberals reinstated its funding in 1994. The Program was steadily supported until it was defunded most recently by the Harper government in 2006, maligned as part of the supposedly wasteful spending of which CSO funding was also part. For supporters of the CCP, its elimination was seen as an ideological decision to further immunize the government from challenges by so-called "interest groups" denigrated by Morton and others. They lamented the fact that these interest groups - many funded by the very governments whose laws they are challenging - have increasingly turned to the courts to advance their policy objectives. The Charter has made the courtroom a new arena for the pursuit of politics." ${ }^{29}$ These critics suggest that individuals, entrepreneurial CSOs, and activist judges have exploited the Charter to "constitutionalize policy preferences that could not easily be

124 FL Morton \& Rainer Knopff, "Judges, the Court Party and the Charter Revolution” (April 2000) Policy Options 55 at 55.

125 Michael H Posner \& Candy Whittome, “The status of human rights NGOs” (1993-94) 25 Colum HRL Rev 269.

126 Boaventura de Sousa Santos, "Toward a Multicultural Conception of Human Rights" in Berta Hernandez-Truyol, Moral Imperialism: A Critical Anthology (New York: New York University Press, 2002) at 43.

127 Larissa Kloegman, “A Democratic Defence of the Court Challenges Program” (2007) 16:3 Const Forum Const 107 at 107-108.

128 Voices-Voix, Court Challenges Program, online: Voices-Voix Coalition $<$ http://voices-voix.ca $>$.

129 Morton, supra note 124 at 628. 
achieved through the legislative process." ${ }^{130}$ Sujit Choudhry and Claire Hunter, however, found no empirical evidence to support claims that the Supreme Court of Canada has engaged in judicial activism. Their analysis of the data showed that the government wins the overwhelming majority of constitutional challenges brought to majoritarian decisions and that judicial activism has not increased over time. ${ }^{131}$

It is understandable that the Charter project found a great deal of support from the social justice community. Fudge and Glasbeek describe the Charter's attractiveness as stemming from the fact that it is "a contemporary instrument, said to have been specifically enacted to ensure amelioration of the lot of the marginalized, and because it is seen by politics of rights proponents as providing a window of opportunity." ${ }^{\prime 32}$ It also emerged as part of the shift towards litigation as the key site of the negotiation of disputes in several areas of life in industrialized societies, not only in the area of human rights. ${ }^{133}$ The allure of the rights discourse for social movements is clear, in that it provides a mechanism for claims to be recognized and implemented more immediately than other forms of political organizing. However, while Charter litigants and their advocates have raised the ire of conservative critics, there are also sceptical voices emerging from the left.

Many scholars have problematized the emancipatory potential of the human rights framework and have the same worry that human rights law has displaced politics as the primary tool of social organizing, albeit for different reasons than the conservative critics. This idea, which can be described as the judicialization of politics, has concerned several scholars in the post-welfare state era. ${ }^{134}$ Read from such a perspective, the Charter is best understood as a liberal text, rather than a progressive one. The suggestion that formal legal equality and the new bill of rights has not delivered the socio-economic or gender, racial, and sexual justice promised is not new. ${ }^{135}$ Since rights are conferred to individuals rather than groups and communities, their capacity to address systemic harms of poverty and violence are limited. ${ }^{136}$ The nature of litigation is transactional and focused on a discrete and definable injury; this is different from the broad-based social goals that most CSOs are working for. Traditionally, rights primarily confer protections from state interference rather than providing a basis to make claims to social and economic welfare from the state. ${ }^{137}$ In addition, the Charter's reach only gives it jurisdiction

130 Ted Morton \& Rainer Knopff, The Charter Revolution and the Court Party (Peterborough: Broadview Press, 2000) at 25.

131 Sujit Choudhry \& Claire E Hunter, "Measuring Judicial Activism on the Supreme Court of Canada: A Comment on Newfoundland (Treasury Board) v NAPE" (2003) 48 McGill LJ 525.

132 Judy Fudge \& Harry Glasbeek, "The Politics of Rights: Politics with Little Class," (1992) 1:1 Soc \& Leg Stud 45 at 52.

133 David Jacobson \& Galya Ruffer, "Courts Across Borders: The Implications of Judicial Agency for Human Rights and Democracy," (2003) 25:1 Hum Rts Q 74.

134 Torbjorn Vallinder, "The Judicialization of Politics: A World-wide Phenomenon: Introduction" (1994) 15:2 International Political Science Review 91; Christopher Manfredi, "The Judicialization of Politics: Rights and Public Policy in Canada and the United States" in Keith G Banting, Richard Simeon \&George Hoberg, eds, Degrees of freedom: Canada and the United States in a Changing World (Montreal: McGill-Queen's University Press, 1997).

135 See for e.g. Dean Spade, "Intersectional Resistance and Law Reform" (2013) 38:4 Signs 1031; Joel Bakan, Just Words: Constitutional Rights and Social Wrongs (Toronto: University of Toronto Press, 1997).

136 Allan C Hutchinson \&Andrew Petter, "Private Rights/Public Wrongs: The Liberal Lie of the Charter" (1988) 38:3 UTLJ 278.

137 Ibid. Recent judgments, however, demonstrate a broader interpretation of what positive obligations human rights law imposes on the government. In Moore v British Columbia (Education), 2012 SCC 61, [2012] 3 SCR 360, for example, the Supreme Court affirmed that human rights law requires public education service providers to provide the 
over the actions of government, even though the potential to suffer harms at the hands of private actors has increased as they become more increasingly present in Canadians' social and economic lives.

The turn to law as the site for social change also exacerbates the problem of the professionalization of social justice organizing discussed above. The displacement of the terrain of civil society-government conflict to the legal arena is another way that Canadian CSOs have abandoned more contentious forms of politics in favour of liberal approaches. This discussion was not intended to suggest that CSOs abandon a rights-based framework, rather it is to caution against an approach that would isolate the Charter and international human rights as the primary means to further their aims. It is a suggestion to consider judicial strategies as one of many sites of struggle in a range of options for social justice actors.

\section{THE COSTS OF CONSENSUS}

The history of the civil society sector detailed in this paper demonstrates the clear intention of leading civil society organizations to carve out an institutionalized space in Canadian governance structures. Civil society organizations and their leaders carved out space through the work of grand-scale, national projects, like the Voluntary Sector Initiative, but the innumerable agreements made by individual organizations with the government to provide research and social services in exchange for funding were equally important. We have seen how successive federal governments recognized and legitimated this form of civil society engagement in governance for several decades of the postwar period, and in turn how these governments began to undermine this relationship, first using justifications of fiscal constraints and later attacking the very legitimacy of organized public participation in decision-making. We have also explored some of the costs of such relationship-building exercises. The effort to appease government patrons has led Canadian civil society to move towards the mainstream, in terms of organizational structure, composition, and strategy. These choices are as important as the regulatory and legal structure governing CSOs, and are crucial for understanding some of the frustrations of members of the sector today.

Phillips describes the series of decisions by government and CSOs that led to the abandonment of poverty as a focus of national concern in Canadian politics. ${ }^{138}$ In response to funding pressures in the late 1980s, anti-poverty CSOs shifted their focus from poverty in general, to child poverty, which had the effect of "significantly narrowing public debate on inequality and welfare state restructuring." "139 While this turn did produce some favourable outcomes, namely a House of Commons resolution to end child poverty by the year 2000 and the formation of a new national coalition of CSOs with anti-poverty missions and those focused on children and families (Campaign 2000), there were also important costs associated with the change in focus. The capacity of anti-poverty groups to reignite the debate on poverty in general were hampered by the structural problems discussed in the previous section, specifically unresolved questions related to the lack of representation of the poor amongst their membership and a disproportionate focus on research to the detriment of advocacy work. Over time the focus on child poverty was replaced by an even more politically palatable issue; as child development

accommodation that persons with disabilities require to access and benefit from that education. See also Canadian Doctors for Refugee Care v Canada (Attorney General), 2014 FC 651.

138 Phillips, supra note 65.

139 Ibid at 170. 
became the common interest of the government, advocacy organizations and experts. Thus, poverty became child poverty, which in turn became child development, and this latest focus was not based on redistributive justice but rather on the idea of "investing" in children as a way to create future economic gains for individuals and society. ${ }^{140}$

This story is unsurprising when we recall that the major policy focus of leading CSOs on the national scale has been on building consensus with the federal government. The VSI was largest concerted effort of the CSO sector and its stated goal was to "improv[e] the working relationship between the government and the voluntary sector in order to better serve Canadians." ${ }^{, 141}$ The language of the Joint Tables spoke of the relationship of the government and CSOs in conciliatory terms, invoking the "long history of joining forces to achieve mutual goals," "work[ing] together," and "forg[ing] a more effective, strategic relationship" to achieve their "common goal" and "shared vision." 142 This consensus-seeking language did not merely indicate the lofty goals in the minds of the VSI's creators in civil society and government, as the initial policy proposals for the initiative included the creating responsibility for the sector-government relationship at the ministerial level, periodic meetings between Cabinet Ministers and CSO leaders, annual reporting to Parliament by CSOs, the creation of a secretariat, and even the establishment of a permanent organization responsible for government-voluntary sector relations. ${ }^{143}$ From this view, the VSI could be seen as part of the "rejuvenation of the public sphere" in which organizations are given a formal platform to participate in deliberative democracy. ${ }^{144}$ The disproportionate focus of CSOs on the funding question is informed by the idea that more opportunities for cooperation and more financial support from the government will create the conditions for dialogue that is necessary for us to come to a shared understanding of the good society.

In contrast, a perspective based on dissent or conflict, rather than one on consensus-based legitimacy, may provide the necessary stimulus for the CSOs to resume their focus on the advocacy and representative activities that draw attention to the power relations and the structural barriers to equality in Canadian society. This capacity was hindered by the government's move away from the core funding model and the Income Tax Act requirements, but CSOs have also censored themselves in order to secure their funding and to develop closer ties to decision makers. Instead of viewing power as centralized in the arms of government, we can consider the ways in which various subjects come to discipline themselves, without need for state coercion. ${ }^{145}$ The previous section provided examples of the various ways in which CSOs moderated their own identities and approaches to politics, which included

140 Alexandra Dobrowolsky \& Denis Saint-Martin, "Agency, actors and change in a child-focused future: problematizing path dependency's past and statist parameters," (2002) Université de Montréal Working Paper No. 3, Fostering social cohesion: a comparison of new policy strategies,; Jane Jenson, "Changing the Paradigm: Family Responsibility and Investing in Children" (2004) 29:2 Canadian Journal of Sociology 169, as cited in Phillips, supra note 67 at 171.

.

"Working Together: A Government of Canada/Voluntary Sector Joint Initiative- Report of the Joint Tables" (1999), online: Voluntary Sector Initiative $<$ http://www.vsi-isbc.org $>$ at 9 [Joint Tables Report].

143 Ibid at 10.

144 Samantha Ashenden, "Questions of Criticism: Habermas and Foucault on Civil Society and Resistance" in Samantha Ashenden \&David Owen, eds, Foucault Contra Habermas: Recasting the Dialogue between Genealogy and Critical Theory (London: Sage Publications, 1999) 143 at 151.

145 Mitchell Dean, "Normalising Democracy: Foucault and Habermas on Democracy, Liberalism and Law" in Samantha Ashenden \& David Owen, eds, Foucault Contra Habermas: Recasting the Dialogue between Genealogy and Critical Theory 166 at 169 . 
professionalization and the legalization of politics. If social justice CSOs feel impotent, it is unsurprising, as the consensus ethic "would not signify an end to power, [rather] it would be to regulate power." " been criticized for failing to consider the extent to which the state retains control of the policymaking process and how the participation of civil society groups in turn legitimizes that power. ${ }^{147}$ The case of the UK's civil society sector is illustrative of this assertion. The idea of the consensus model as a legitimation of state power is manifested in the case of the British civil society sector, which is typically described in enviable terms in the civil society policy literature. As the funding cuts to the civil society sector in Canada are characteristically representative of conservative politics, it may be surprising to learn that in the UK, Margaret Thatcher's government actually tripled funding for the voluntary sector was from $£ 93$ million in 1987 to $£ 293$ million in $1989 .{ }^{148}$ Over the same time period, almost 40,000 new charities registered themselves with the government. ${ }^{149}$ This was an attempt by Thatcher to revive what she considered to be Victorian-era values of voluntarism and self-help, while at the same time serving as a policy that would ostensibly allow her to curtail the scope of government activities.

An overreliance on the support of the state creates a situation of structural dependency for civil society, leaving groups too vulnerable to economic or political downturns in funding. It also leaves organizations susceptible to what New York social worker Jennifer Samimi has called "mission drift," the phenomenon in which an organization moves further and further away from its mission to secure funding, which eventually results in a loss of its original reasons for existing. ${ }^{150}$ However, there are also other consequences of the consensus-based approach to civil society. The use of charity law and contract-based funding represents a form of metagovernance, in which the state regulates the contours of the relationship between social actors under the guise of public participation. ${ }^{151}$ In the UK, the first observed shift was the move from grants to contracts, which created a "contract culture" in which CSOs increasingly filled the gaps in social services that were slashed by the Conservatives. Next was the move from looking at civil society as an "organizational" or political experience to one based on civil society engagement as characterized by voluntarism, an "individual" pursuit. ${ }^{152}$ Fast-forward to the present day, and the current Conservative government under David Cameron is increasing support for the third sector through a similar strategy called The Big Society. ${ }^{153}$ By devolving responsibility for service provision to churches, charities, and CSOs, the state effectively passes off its duty to ensure the wellbeing of its

146 Flyvbjerg, supra note 44 at 227.

147 Jonathan Davies, Challenging Governance Theory: From Networks to Hegemony (Bristol: The Policy Press, 2011), as cited in Nicholas Acheson \& Rachel Laforest, "The Expendibles: Community Organizations and Governance Dynamics in the Canadian Settlement Sector" (2013) 46:3 Canadian Journal of Political Science 597 at 600. George Campbell Gosling, "Margaret Thatcher and the Voluntary Sector" (17 April 2013), online: Voluntary Action History Society $<$ http://www.vahs.org.uk>.

149 Tania Mason, "Sector faced many similar challenges in 1980s Britain, shows report" (10 April 2013), online: Civil Society Governance $<$ http://www.civilsociety.co.uk $>$.

150 Jennifer C Samimi, "Funding America's Nonprofits: The Nonprofit Industrial Complex's Hold on Social Justice" (2010) 1 Columbia Social Work Review 17.

151 Acheson \& Laforest, supra note 147 at 601.

152 N J Crowson, "Introduction: The Voluntary Sector in 1980s Britain" (2011) 25:4 Contemporary British History 490.

153 Stephen Evans, “"Mother's Boy': David Cameron and Margaret Thatcher" (2010) 12:3 British Journal of Politics and International Relations 325. 
citizens and in turn has leverage to regulate the activities of social organizations through the funding system.

One crucial outcome of this form of rule is that it "sustain[s] the fiction that the meaning of social problems is beyond contestation and is a matter for technical expertise alone." ${ }^{\prime 54}$ This clearly relates to the professionalization of social justice work and the move from community-based organizing to a technocratic model. Flyvbjerg reminds us that inequality and domination was built into the concept of civil society from the outset, as the establishment of this public presence necessarily entailed the exclusion of some groups, women in particular. ${ }^{155}$ Today, we can broaden this understanding of exclusion to consider the relative marginalization of racial and ethnic minorities and low-income people from leadership positions in the civil society sector, and we have seen the inadequacy of the Canadian civil society sector's response to this. Discussions of "exclusion, difference, diversity, and the politics of identity" should not be limited to oppression from the state or corporations; CSOs must examine the structural inequities that they reproduce within their own organizational structures, programs, and discourse. While representatives of large, well-established CSOs lament the evaporation of state support today, they may want to turn to chronically underfunded CSOs, fighting for more radical forms of social justice, to learn about survival strategies.

\section{CONCLUSIONS: PRINCIPLED ENGAGEMENT, A WAY FORWARD?}

We have attempted to assess the power and effectiveness of Canada's civil society sector beyond the myopic focus on funding. Although the past decade may have been particularly challenging in terms of antagonistic relationship between the government and the civil society, we find that levels of political, institutional, and financial support for the civil society sector has waxed and waned since the foundation of the modern Canadian state. While acknowledging that financial support for civil society declined under the Conservative government, we have also tried to demonstrate that the question of the level of funding is not the most important consideration in assessing the strength of Canada's civil society sector. Firstly, government support has never been equally distributed amongst all civil society actors: large scale, mainstream, and service-driven CSOs receive disproportionate amounts of government transfers, at the expense of grassroots, community-based organizations with more radical agendas or representing non-majority groups. Secondly, we have also seen how the pursuit of a close financial and institutional relationship with government creates dependency, which has unintended and potentially harmful consequences for organizations, their constituents, and their clients.

On the sectoral level, Canadian civil society organizations are urged to establish new alliances and create a new framework for reinvigorated engagement. Thus far, the sector has been wary of private funding for philanthropy and advocacy, ${ }^{156}$ as many organizations are rightly concerned with the influence of corporate interests or management styles on social justice projects. ${ }^{157}$ The largest and most influential organizations have also maintained a distance from old allies in social movements and grassroots community organizations, in a cynical effort to maintain a "positive" working relationship

154 Ibid.

155 Flyvbjerg, supra note 44 at 212.

156 Valverde, supra note 22 at 35.

157 Michael Edwards, “Philanthrocapitalism' and its limits,” (2008) 10 International Journal of Not-for-Profit Law 2. 
with the government by appearing as non-controversial as possible. ${ }^{158}$ Our observations lead us to believe that majority of the large CSOs now sit somewhere in the middle, and while the funding outcomes may have been not so unfavourable, the space for their engagement in decision-making has shrunk significantly. The unfortunate truth of the mainstream Canadian civil society sector is that the compromise it made by quieting its voices in an effort to occupy more space and power has not yielded the desired results, and some organizations may have lost some of their legitimacy in the eyes of their constituents and the communities they claim to work for.

Must the Canadian CSO sector choose between a path of consensus and one of conflict? If we view these approaches as two opposite poles on a spectrum, perhaps the majority of Canadian CSOs would fall at various points near the centre. Most groups are neither completely anti-statist, nor are they organizations in completely symbiotic relationships with government and business. The majority are somewhere along this spectrum, attempting to assert their independence from government while accepting the necessity of seeking state funding to which they have become accustomed. While governments come and go, CSOs can and must maintain a coherent ethos that guide their interactions with the state and other stakeholders. Institutional changes ought to be informed by a careful reflection on changing demands and aspirations of all constituencies the organization serves and not just based on the caprices of the funding regime. The generous support that some segments of the CSO sector received from the government in the past "appears to have been offered without a coherent and articulated policy or strategy to justify it." 159 Thus, we advocate for a spirit of principled engagement to underlie the approach of social justice CSOs to their relationship with government. What we offer is not a detailed, step-by-step guide for organizations to gain autonomy and political legitimacy. We acknowledge the underlying structural obstacles for CSOs, recognize the diversity of profiles and agendas, and make a modest proposal for reflection and the reimagining of possibilities.

A principled engagement approach urges CSOs to carefully reflect over the values integral to their mission. The final report of the Joint Tables claims that "Canada has a strong tradition of voluntary action" and that "since pioneering days, Canadians have helped each other meet daily needs and overcome hardships." 160 This is not so much a statement of principle as it is a statement of fact. Recall the idea of the history of the Canadian state as a mixed economy of welfare, rather than a welfare state based on a deliberate intention for the government to ensure the wellbeing of all citizens. The goal of the VSI, to improve the relationship between the CSO sector and government, and thereby increase access to power and resources, is not a principled one. The list of successfully completed activities of the VSI showed how the major focus was on creating products as tangible outputs of cooperation, such as awareness-raising campaigns, reports, and training manuals. ${ }^{161}$ These goals were in the interest of improving the "wellbeing" and "quality of life" of Canadians, but there appears to have been little to no discussion about exactly what those ideas entail and the form of politics by which they should be achieved. Organizations should avoid these pitfalls by having serious discussions with their members about its identity: Should our approach be based on charity or redistributive politics? What type of organizational and leadership structure should we adopt? Does this reconcile with our mission? Should

158 Aziz Choudry \& Eric Shragge, "Disciplining dissent: NGOs and community organizations," (2011) 8 Globalizations 4.

159 Miller, supra note 29 at 408.

160 Joint Tables Report, supra note 144 at 15.

161 VSI Final Report, supra note 110 at 5-7. 
we mostly engage paid staff or volunteers? Can "professionalism" and education compensate for lack of attachment to the community? Are we legitimate interlocutors in defining what constitutes "public space"?

The principled engagement approach, while acknowledging the existing political landscape, urges CSOs to be guided by the principles of social justice. Canadian civil society falls somewhere in between the Latin American participatory democratic model, and the American one, where private foundations wield significant power in the voluntary sector. Due to historical factors, the structure of the Canadian civil society sector is an "amalgam" of the welfare partnership model of Western Europe, as well as the Anglo-Saxon model of development. ${ }^{162}$ While we have a relatively high level of government support for CSOs, as in the welfare model, we also have more private philanthropic support and volunteerism than the sector in Western Europe; which is more in line with the United Kingdom, the United States, and Australia. Rather than making claims to an idealized vision of Canada, civil society actors must recognize that there has never been a perfect consolidation of the welfare state in this country, and recalibrate their expectations accordingly. Such a view may open opportunities to CSOs to seek partnerships with private entities, on a principled basis. It is no secret that diversifying funding sources would allow organizations greater freedom and flexibility to pursue alternative agendas, but the relative dearth of private philanthropic foundations in Canada makes this task more difficult, and the conservatism of many of these funders would subject CSOs to trade-offs similar to those imposed by the government. No model will work for every organization, but looking past the material and political dependence on a single source may reveal potentially fruitful new opportunities.

The principled engagement proposal is most relevant to social justice CSOs that want to continue working with the government, whether for reasons of financial necessity or a belief in the productive potential of this relationship. It also assumes that the government will apply administrative fairness in its decision-making processes that affect the funding of CSOs, a caveat that should not be taken for granted in light of mounting evidence that the federal government has used its oversight over the regulation of charities to silence certain elements of civil society. ${ }^{163}$ Of course, any partnership with a third party will reduce the absolute autonomy of an organization, hence a call for "principled engagement" rather than "cooperation." Cooperation describes a process in which multiple actors work together to the same end. The mainstream of the CSO sector in Canada has sought cooperation with the government for too long, even though in many cases their mandates had divergent interests, with only a shared, ambiguous notion of "social wellbeing" in common. A principled engagement, on the other hand, invokes an agreement in which all sides enter into a partnership with transparent agendas and honest expectations. Cooperation suggests a structural position, which may put CSOs in a compromised position. By making negotiation and strategic partnering guiding principles in the relationship to government, the principled engagement approach should ensure greater autonomy and integrity for CSOs.

The suggestion that CSOs can approach their relationship with the state and non-state actors on a basis of principled engagement does not apply to all organizations. As stated above, many organizations

162 Hall et al, supra note 8 at 20 .

163 See e.g. Voices-Voix, "Submission to the UN Periodic Review" (7 October 2012), online: Voices-Voix <http://voicesvoix.ca/sites/voices-voix.ca/files/upr_submission_voices-voix.pdf $>$. At the time of its submission to the UN Periodic Review, Voices-Voix had documented 35 cases of government efforts to defund and silence elements of civil society since 2010 . 
have never had a close financial or institutional rapport with the government. Organizations with radical agendas have openly expressed their interest in acting against or parallel to the state, and as such, have never pursued government support. For organizations with more dissent-based goals and strategies that do have charitable status, and feel that either that they must choose between their mission or maintaining funding, relinquishing charitable status and state funding is an option. Some organizations have become split entities, dividing activities between a charity with an educational mandate and an advocacy organization that operates free from government strictures, such as the Pembina Foundation and the Pembina Institute, an environmental research and education centre with charity status and a nonregistered advocacy think tank, respectively. ${ }^{164}$

Even if an organization is interested in continuing its relationship with the government, it still has much to learn from groups that have either rejected or been excluded from the inner circle. In their excellent study of the strategies that influence the survival of community-based organizations, Walker and McCarthy found that engaging in even a limited amount of grassroots fundraising is beneficial for organizations. ${ }^{165}$ For organizations that are based in low-income communities and purport to work for the interests of poor people, grassroots fundraising is especially important, as it not only allows the organization to diversify its resource streams and immunize itself from dependency to a single patron, but it also bolsters the local political legitimacy of the organization through its very methods.

The example of the Sylvia Rivera Law Project [SRLP] can provide organizations with valuable insights into the methods and ethics of a grassroots funded organization. The SRLP is an organization in New York City that provides legal services to low-income transgender, intersex, and gender nonconforming people. The group does training, public education, policy reform, and strategic litigation to end state discrimination on the basis of gender identity. It was founded by a white, trans law graduate with foundation money and was housed in a traditional legal clinic, but over the years it has made deliberate efforts: to ensure that it is led predominantly by trans, intersex, and gender non-conforming people of colour; reject hierarchical modes of organization; and reduce dependence on the nonprofit industrial complex by engaging in serious grassroots fundraising. ${ }^{166}$ Three years after its founding, the organization was able to raise $30 \%$ of its budget from individuals and families, through a combination of methods: the collecting of a database of thousands of collaborating social and medical service providers, lawyers, activists, and students; publishing a simple, bi-annual newsletter; conducting a direct mail appeal urging action on a time-sensitive case; and throwing fundraising and networking house parties for potential donors. ${ }^{167}$ Importantly, the organization shares information and strategies with allied groups when it does seek funding from traditional donors and even declining to compete for grants when there may be a more appropriate group that should receive it.

In 2015 it is trite to say that the internet is a valuable tool and space for fundraising and political organizing, but many Canadian CSOs have not exploited its full potential. The social movements from

164 The Pembina Foundation for Environmental Research and Education, About the Pembina Foundation, online: Pembina Foundation $<\mathrm{http}: / /$ www.pembinafoundation.org/about $>$ and The Pembina Foundation for Environmental Research and Education, About Pembina, online: Pembina Institute $<$ http://www.pembina.org/about/about-pembina $>$. Edward T Walker \& John D McCarthy, "Legitimacy, Strategy, and Resources in the Survival of Community-based Organizations," (2010) 57:3 Social Problems 315.

166 Mananzala \& Spade, supra note 116 at 63-68.

167 Dean Spade, "Getting it Right from the Start: Building a Grassroots Fundraising Program" (2005 January/February) Grassroots Fundraising Journal 10. 
which mainstream nonprofits have strayed ever further are all active online; some were even generated from social media sources. While one of the aims of the Occupy Movement was to take up physical space in the hearts of cities, this was made possible by the "networked organization" of the crowd via text message, email, blogs, websites, Facebook, YouTube, Twitter, and live streaming. ${ }^{168}$ The highly decentralized nature of the movement although demonstrated the weakness in terms of the lack of coherent mission and direction, it also demonstrated its immense capacity to mobilize, respond, and connect disparate networks with the assistance of cost effective new technologies. Far from being "a shallow bid for fleeing attention," online activism is proving to be a substantial political force in the United States, where a new generation of anti-racism activists are developing into powerful organizers, through traditional means and importantly, through Twitter and other social media. ${ }^{169}$ The viral \#blacklivesmatter hashtag and the widespread protests against police brutality that it helped the organizers to mobilize in US cities in late 2014 to early 2015 serve as proof that these forms of civil society action should be taken seriously. The lesson here is not for CSOs to co-opt social movement actions but rather to reinvigorate their social missions by becoming effective partners in these networks. These partnerships should not only benefit the formal organizations, but formal organizations should also lend their institutional and political resources to the movements. For example, a CSO that has lawyers on its staff could provide legal support to people arrested at protests; established organizations could give access to movements and grassroots organizations by inviting their representatives as their guests at meetings with decision-makers and allowing these guests to frame the agenda.

The current inhospitable climate for Canadian nonprofits is but one in the long history of an uncertain, unprincipled relationship with government. The status quo is one of CSOs modifying their goals to appease governments that may be indifferent or overtly hostile to their interests, sighing in relief each time funding is renewed, and lamenting the extinction of less fortunate organizations. This, despite the fact that indigenous community organizer Andrea del Moral reminds us that "the goal [of social justice movements] is not for each organization to last forever. Rather than cement a particular organization in place, people ought to be able to reframe issues and change their work as times changes." ${ }^{170}$ If civil society is not simply the sector of non-profit organizations, the, preoccupation of CSOs has to move past the question of how to secure an everlasting source of funding for organizations; the goals of creating structural political and economic change and providing perpetual employment for a class of civil society professionals are incompatible. By engaging in truly participatory politics, both internally as well as in concert with other organizations, social movements, and common citizens, civil society organizations can reclaim the space as the vibrant third sector of Canada. We hope that future strategic dialogues between the civil society sector and the government will focus on substantive issues of poverty, growing income inequality and the welfare of the marginalized communities, with the aim of strengthening democratic processes and institutions in Canada.

\footnotetext{
168 Sheetal D Agarwal et al, "A Model of Crowd-enabled Organization: Theory and Methods for Understanding the Role of Twitter in the Occupy Protests," (2014) 8 International Journal of Communications 646.

169 Jay Caspian Kang, "Our demand is simple: stop killing us”, New York Times Magazine (10 May 2015) online: New York Times < http://www.nytimes.com/2015/05/10/magazine/our-demand-is-simple-stop-killing-us.html>.

170 Andrea del Moral, "The Revolution will not be Funded,” LiP Magazine (4 April 2005) 1, online: Lip $<$ www.lipmagazine.org $>$.
} 